\title{
RE-REDUCTION OF THE OLD PHOTOGRAPHIC OBSERVATIONS OF INTERAMNIA (704) BASED ON GAIA DR2 REFERENCE CATALOGUE
}

\author{
Yu.I. Protsyuk, N.V. Maigurova \\ Research Institute "Mykolaiv Astronomical Observatory", Ukraine \\ yuri@nao.nikolaev.ua,nadija@nao.nikolaev.ua
}

\begin{abstract}
A new astrometric reduction of old photographic astroplates benefiting from integration of modern technologies such as the high precision digitizing machines and the high precision Gaia DR2 catalogue could be useful to study the orbital motion of Solar system minor bodies. Based on the newly released Gaia DR2 star catalogue, the scans of the photographic plates containing images of Interamnia (704) taken by the Zonal Astrograph of Mykolaiv Astronomical Observatory (MAO) in 19741985 were re-reduced. For our investigation we used 29 plates from the UkrVO archive digitized by commercial EPSON scanner with 1600 dpi resolutions. Besides for 2 of them were digitized by the high precision digitizing machine of Shanghai Astronomical Observatory of the Chinese Academy of Sciences (ShAO) with 2540 dpi resolution. Almost all the plates have 3 exposures with a small shift. Each of 29 plates was scanned 6 times by EPSON scanner in $0^{\circ}$ direction. The ShAO digitizing machine scanned 2 plates also 6 times but 3 times in $0^{\circ}$ direction and 3 times in $90^{\circ}$ direction. Totally, 85 asteroid positions taken from 29 plates were derived. Only 5 asteroid positions were calculated from ShAO scans.
\end{abstract}

The full identification was conducted and coordinates of all objects were obtained with usage of different options of astrometric reductions. The mean inner accuracy of obtained asteroid positions is $0.03^{\prime \prime}$ in RA and 0.14" in DEC for EPSON scanner and 0.014" in RA and 0.013" in DEC for the ShAO digitizing machine in $0^{\circ}$ direction and $0.010^{\prime \prime}$ in RA and $0.011^{\prime \prime}$ in DEC in $90^{\circ}$ direction. The comparison of the new topocentric asteroid positions with Horizons ephemeris was made for calculation $(\mathrm{O}-\mathrm{C})$ residuals and their RMS. The mean residual differences between the scan obtained positions and JPL calculated positions were $(0.09 \pm 0.16)^{\prime \prime}$ in RA and $(-0.09 \pm 0.25)^{\prime \prime}$ in DEC for the MAO digitized plates; the calculated differences for the ShAO scans are close to zero. Comparison of the results obtained with previous reductions of these observations with Tycho 2 and UCAC4 reference catalogues showed that the use of the Gaia DR2 reference catalogue does not lead to a significant improvement in the random and systematic component of the residual differences $(\mathrm{O}-\mathrm{C})$ for scans with EPSON scanner from the UkrVO archive. The results obtained by processing images with the ShAO digitizing machine suggest that in this case, the re-reduction of all photographic observations based on the Gaia DR2 could improve the accuracy of old photographic observations to the level of modern ground-based CCD observations.

Keywords: asteroids, photographic observations, ephemeris, reference catalogue.

АНОТАЦІЯ. Нові астрометричні редукції старих фотопластинок із використанням сучасних технологій, таких як високоточні машини для оцифрування, у поєднанні з опорним високоточним каталогом Gaia DR2, можуть бути корисними для вивчення орбітального руху малих тіл Сонячної системи. Для сканів фотопластинок із зображеннями астероїда Інтерамнія (704), що були отримані на Зонному астрографі Миколаївської астрономічної обсерваторії (МАО) у 1974-1985 pр., виконано нові астрометричні редукції. Для нашого дослідження ми використали 29 пластинок з архіву УкрВО, оцифрованих комерційним сканером EPSON 3 роздільною здатністю $1600 \mathrm{dpi}$. Крім того, дві з них були оцифровані за допомогою високоточної машини для оцифрування Шанхайської астрономічної обсерваторії (ШАО, КНР) з роздільною здатністю 2540 dpi. Майже всі пластинки мають 3 експозиції з невеликим зсувом. Кожна з 29 пластинок була сканована 6 разів сканером EPSON у напрямку $0^{\circ}$. Оцифрувальна машина ШАО сканувала 2 пластинки також 6 разів, але 3 рази у напрямку $0^{\circ}$ та 3 рази у напрямку $90^{\circ}$. Загалом були отримані 85 положень астероїда 329 пластинок. Зі сканів, отриманих в ШАО, було отримано лише 5 положень астероїдів.

Була проведена повна ідентифікація та отримані екваторіальні координати всіх об'єктів 3 використанням різних варіантів астрометричних редукцій. Середня внутрішня точність отриманих положень астероїда становить 0.03 " за прямим піднесенням (RA) i 0.14" за схиленням (DEC) для сканера EPSON i $0.014 "$ за RA i 0.013" за DEC для машини ШАО в напрямку $0^{\circ}$ i $0.010^{\prime \prime}$ за RA і $0.011^{\prime \prime}$ за DEC в напрямку $90^{\circ}$. Порівняння нових топоцентричних положень астероїду Інтерамнія 3 ефемеридами Horizons було проведено для розрахунку остаточних різниць $(\mathrm{O}-\mathrm{C})$ та їх середньоквадратичних похибок. Середні остаточні різниці між отриманими зі сканів та розрахованими положеннями за ефемеридою JPL становили $(0.09 \pm 016)^{\prime \prime}$ за RA та $(-0.09 \pm 0.25)^{\prime \prime}$ за DEC для пластинок, що оцифровані сканером EPSON, а для сканувань ШАО значення остаточних різниць несуттєво відрізняються від нуля. Порівняння результатів, отриманих з попередніх астрометричних редук- 
цій цих спостережень, що було виконано $з$ опорними каталогами Tycho2 та UCAC4, показало, що використання опорного каталогу Gaia DR2 не призводить до значного поліпшення випадкової та систематичної складової остаточних різниць (О-С) для зображень 3 архіву УкрВО, що отримано сканером EPSON. Результати, отримані з використанням зображень, що зроблено машиною ШАО, дозволяють припустити, що в цьому випадку повторні астрометричні редукції старих фотографічних спостережень 3 опорним каталогом Gaia DR2 можуть підвищити точність положень 3 фотографічних пластинок до рівня сучасних наземних ПЗ3 спостережень.

Ключові слова: Астероїди, фотографічні спостереження, ефемериди, опорні каталоги.

\section{Introduction}

The studied astroplates were taken with the Mykolaiv Observatory Zone astrograph $(\mathrm{F}=2044 \mathrm{~mm}, \mathrm{D}=120 \mathrm{~mm}$, FoV $\left.5^{\circ} \times 5^{\circ}\right)$. The telescope was removed to Mykolaiv from Pulkovo in 1959 with the aim to expand declination zone up to $-20^{\circ}$ for Solar system minor bodies' observations. The telescope has a four-element lens that has a minimum of aberration. The regular observations of selected asteroids with this telescope were conducted during 36 years (1961-1997). Unfortunately, the low aperture ratio of the instrument did not allow obtaining good quality images for objects fainter than $12^{\mathrm{m}}$. In total, 2450 positions of 19 asteroids of the main belt were obtained. All observational data were processed in the international ICRS system with the AC TRC reference catalogue (Gorel et al., 2000). For the first time, the mean accuracy of the positions of a long series of photographic observations turned out to be better than 0.2", which makes these observations valuable material for solving a number of problems of ephemeris astronomy.

Since 2007, the work on digitizing glass plates in order to saving and further using the old observations has begun at the Mykolaiv Observatory (Protsyuk et al., 2007, 2014a; Vavilova et al., 2010, 2011). In 2016, we processed images of 4 asteroids with EPSON scans in the UCAC4 catalogue reference system (Zacharias et al., 2013). Reprocessing results of plates with Interamnia observations showed the repeats $(\mathrm{O}-\mathrm{C})$ of the system with a slight increase in accuracy (Protsyuk et al., 2016). In this paper, we present the results of astrometric rereductions of EPSON scans using the high-precision Gaia DR2 (Gaia Collaboration, 2018) catalogue as a reference catalogue, as well as preliminary results of processing of the some scans obtained by the digitizing machine of the Shanghai Astronomical Observatory (ShAO).

\section{Plate Digitization}

Digitization of astroplates at the MAO: we used Epson Perfection V750 Pro scanner and each plate was scanned 6 times with 1600 dpi resolution with same methodic (Protsyuk et al., 2014b, 2014c). Digitization of astroplates at the ShAO: a new digitizing machine was used with 2540 dpi resolution and each plate was scanned 3 times in 2 directions (Zhao et al., 2017).
Table 1: Inner accuracy of coordinates (repeatability) for the Interamnia asteroid (in $0^{\circ} \mid 90^{\circ}$ direction).

\begin{tabular}{l|rcl}
\hline Cat, method & RA, mas & DE, mas & Scanned \\
\hline Gaia DR2, Max & 121 & 153 & MAO \\
Gaia DR2, Mid & 83 & $\mathbf{1 4 2}$ & MAO \\
Gaia DR2, No & $\mathbf{1 9}$ & 372 & MAO \\
Gaia DR2, Max & $74 \mid 64$ & $62 \mid 86$ & ShAO \\
Gaia DR2, Mid & $63 \mid 77$ & $55 \mid 81$ & ShAO \\
Gaia DR2, No & $\mathbf{1 4 |} \mathbf{1 0}$ & $\mathbf{1 3} \mid \mathbf{1 1}$ & ShAO \\
\hline
\end{tabular}
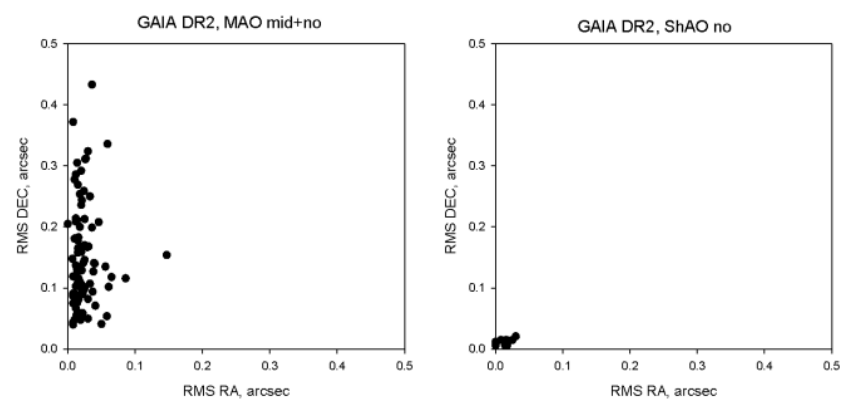

Figure 1: Difference in coordinate repeatability for the Interamnia asteroid with the best methods (bold in Table 1) for the MAO and ShAO scans.

\section{Astrometric Reductions and Accuracy}

The processing of the digitized images to extract asteroid astrometry exploits methods that are quite similar to those for CCD-based image data. The detailed description of all steps of processing of digitized image of astronegatives from the UkrVO archive is given by Protsyuk et al. (2014c, 2014d), Andruk et al. (2014, 2015), Pakuliak et al. (2020). The scan processing includes such steps as follows: preliminary filtering, choosing PSF (point spread function) objects and scheme of astrometric reductions to calculating the equatorial coordinates and magnitudes in a system of the selected reference catalogues.

In this investigation we used UCAC4 and Gaia DR2 catalogues. The limited magnitude of reference stars were $13^{\mathrm{m}}$. Also we check three different model of correction of systematic errors for data from both scanners: "Max" model with 6 iteration, "Mid" model with 4 iterations and "No" model without any correction. For the MAO images we use combined method with 4 iterations for declination and no correction for right ascension (Table 1). Also for the MAO scans we used only 5 from 6 images for all the Interamnia observations with more good inner accuracy. An inner accuracy of reference stars for the reduced MAO images is from less than 0.1 " for "Max" model to 0.5 " for "No" model. An inner accuracy for the ShAO images is from 0.01-0.02" for "Max" model to 0.35" for "No" model. In other case, we have another picture for accuracy of the Interamnia coordinate repeatability (Table 1). 


\section{4. $\quad$ Results}

We have made the comparison of obtained topocentric equatorial coordinates $(\mathrm{O})$ with the ephemeris $(\mathrm{C})$ one provided by on-line service HORIZONS and have calculated the residuals differences $(\mathrm{O}-\mathrm{C})$ in both coordinates for different modes of processing. The mean differences $(\mathrm{O}-\mathrm{C})$ and their standard deviation in both coordinates are presented in Table 2. The last table row shows values of the $(\mathrm{O}-\mathrm{C})$ for glass photographic plates reduction from on-line resource AstDys-2 (https://newton. spacedys.com/astdys/), where $\mathrm{C}$-ephemeris positions are calculated with OrbFit software.

As can be seen from the Table 2 and Fig. 2, the use of modern reference catalogues with the high spatial resolution (such as UCAC4 and Gaia DR2) for processing the digitized images of photographic plates does not lead to a significant improvement in the accuracy of asteroid positions in comparison with the results obtained from processing glass photographic plates. The expansion of the reference system is mainly due to faint stars, and the accuracy of their measurements is limited by the stability of the EPSON scanner.

Table 2: Differences $(\mathrm{O}-\mathrm{C})$ and their standard deviations for the MAO scans of Interamnia asteroid.

\begin{tabular}{l|rccc}
\hline Cat, method & RA, mas & DE, mas & N & Year \\
\hline Gaia DR2, No & $-89 \pm 158$ & & 29 & 2020 \\
Gaia DR2, Max & $19 \pm 299$ & $-85 \pm 251$ & 28 & 2020 \\
Gaia DR2, Mid & $5 \pm 281$ & $-87 \pm 257$ & 28 & 2020 \\
UCAC4, Max & $34 \pm 236$ & $-131 \pm 254$ & 29 & 2020 \\
UCAC4, Mid & $32 \pm 244$ & $-144 \pm 242$ & 29 & 2020 \\
UCAC4 & $-149 \pm 178$ & $-17 \pm 188$ & 29 & 2016 \\
Tycho2, Max & $77 \pm 246$ & $-73 \pm 277$ & 28 & 2020 \\
Tycho2 & $60 \pm 219$ & $-119 \pm 312$ & 29 & 2016 \\
AC TRC & $-204 \pm 165$ & $-87 \pm 208$ & 29 & 1992 \\
(AstDys-2) & & & & \\
\hline
\end{tabular}

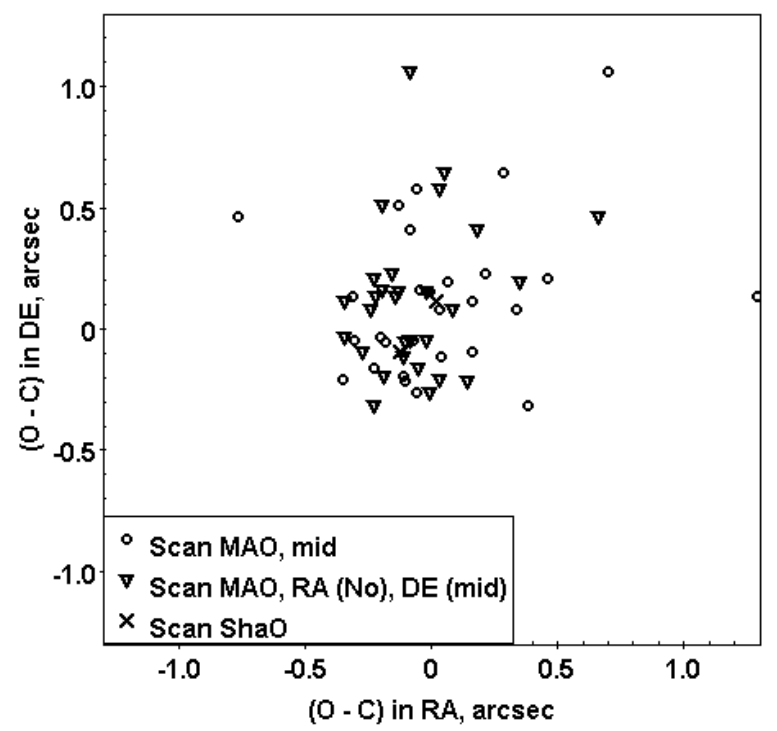

Figure 2: Differences $(\mathrm{O}-\mathrm{C})$ for the MAO and ShAO scans of Interamnia asteroid in Gaia DR2 system.

\section{Conclusion}

Digital scans of 29 photographic plates with images of an asteroid (704) from the UkrVO archive (Vavilova et al, 2010, 2011, 2012a, 2012b, 2014a, 2020; Savanevych et al. 2015, 2018) obtained with the Zonn Astrograph during 1974-1981 were re-reduced in the Gaia DR2 reference catalogue system. The average internal accuracy of the asteroid obtained positions is 0.03 "in RA and 0.14 " in DEC for the EPSON scanner; 0.014" in RA and 0.013" in DEC for scans obtained by the ShAO scanning machine. The mean residual differences between the positions obtained from the scans and the positions calculated by the JPL ephemeris HORIZONS were $(0.09 \pm 0.16)^{\prime \prime}$ in RA and $(-0.09 \pm 0.25)^{\prime \prime}$ in DEC for scans from the UkrVO archive; the corresponding differences for the ShAO scans are close to zero. Comparison of the obtained results with previous reductions of these observations with the reference catalogues Tycho2 and UCAC4 showed that the use of the Gaia DR2 catalogue does not significantly improve the random and systematic component of residual differences $(\mathrm{O}-\mathrm{C})$ for the EPSON scans from the UkrVO archive. The previous results for repeatability obtained with scans using the ShAO scanning machine allow us to suggest that re-reduction of old photographic observations in the Gaia DR2 reference catalogue system could increase the accuracy of old photographic observations to the level of modern ground-based CCD observations.

\section{References}

Andruk V. et al.: 2014, Odessa Astron. Publ., 27/1, 53. Andruk V. et al.: 2015, Odessa Astron. Publ., 28/2, 192. AstDyS-2: 2016, http://hamilton.dm.unipi.it/astdys/ HORIZONS: 2016, http://ssd.jpl.nasa.gov/?horizons. Gaia Collaboration 2018, $A \& A$, 616, A1.

Gorel G. K. et al.: 2000, Kinem. Phys. Cel. Bodies, 16, N5, 463.

Pakuliak L.K., Andruk V.M.: 2020, in: Knowledge Discovery in Big Data from Astronomy and Earth Observation. ISBN: 978-0-128-19154-5 (Elsevier), DOI: 10.1016/B978-0-12-819154-5.00029-1, 325.

Protsyuk Yu. et al.: 2007, Proc. IAU Symp., 248, 548. Protsyuk Yu. et al.: 2014, ISBN: 978-80-7080-918-1, 131. Protsyuk Yu. et al.: 2014, Kinem. Phys. Cel. Bodies, 30, N6, 296

Protsyuk Yu. et al.: 2014, Odessa Astron. Publ., 27/1, 63.

Protsyuk Yu. et al.: 2014, Odessa Astron. Publ., 27/1, 59.

Protsyuk Yu. et al.: 2016, Odessa Astron. Publ., 29, 147.

Savanevych et al. : 2015, MNRAS, 451, 3287.

Savanevych et al. : 2018, Astron. Astrophys., 609, A54.

Vavilova I.B. et al.: 2010, Kosm. Nauka Technol., 16, N5, 62. Vavilova I.B. et al.: 2011, Kosm. Nauka technol., 17, N4, 74.

Vavilova I.B. et al.: 2012, Kinem. Phys. Cel. Bodies, 28, N2, 85 .

Vavilova I.B. et al.: 2012, Baltic Ast., 21, N3, 356.

Vavilova I.B. et al.: 2014, Odessa Astron. Publ., 27/1, 65.

Vavilova I. et al.: 2014, ISBN: 978-80-7080-918-1, 8.

Vavilova I. et al.: 2020, in: Knowledge Discovery in Big Data from Astronomy and Earth Observation. ISBN: 978-0-128-19154-5 (Elsevier), DOI: 10.1016/B978-012-819154-5.00015-1, 57.

Zacharias N. et al.: 2013, Astron. J., 145, 44.

Zhao Yu Y. et. Al: 2017, Res. Astron. Astroph., 17(3), 28. 